\title{
Projekt Komenský 2020
}

\author{
JAN HÁBL
}

\begin{abstract}
Abstrakt: Má lidstvo budoucnost? Smérujeme nezvratitelně do zábuby, nebo máme očekávat lepši zitřky? Jak na tom jsme? Rok 2020 poskytl príležitost promyslet vyhlidky lidstva, byl totiž rokem významného výroči. Když Jan Amos Komenský pred 350 lety zemřel, zanechal po sobè své nejvètši nedokončené dilo s názvem Obecná porada o nápravě věcí lidských. Dílo je to krásné, hluboké a rozsáhlé. Pưvodni rukopis čital nějakých 2000 stran textu. Překlad z latiny do češtiny byl rozvržen do tři svazkü, každý pres pèt set stran. Jedná se tedy o velkolepý projekt, unikátni myslitelský počin, literárni poklad, jeden ze zdroju evropského duchovního dédictví. Dodnes z néj čerpáme. VŽdyt' nejhlubši lidské otázky, které pojednával Komenský, řšíme i dnes. Co jsou to věci lidské, co je s nimi v nepoŕádku, a také otázka nejdưležitějši-daji se nějak napravit, reformovat, polepšit? Projekt Komenský 2020 usiloval o popularizaci Komenského Porady i širšího humanitniho odkazu.
\end{abstract}

Klíčová slova: Komenský, náprava věci lidských, edukace, humanita

\section{IDEOVÉ ZÁZEMÍ PROJEKTU}

Rok 2020 byl rokem významného komeniologického výročí. Když Jan Amos Komenský před 350 lety zemřel, zanechal po sobě své největší nedokončené dílo s názvem Obecná porada o nápravě věci lidských, latinsky De rerum humanarum emendatione consultatio catholica. Komenského Porada je dílo krásné, hluboké a rozsáhlé. Původní rukopis čítal nějakých 2000 stran textu. Jedná se tedy o velkolepý projekt, unikátní myslitelský počin, literární poklad, jeden ze zdrojů českého duchovního dědictví. Byla by škoda $z$ něj nečerpat, vždyt nejhlubší lidské otázky, které pojednával Komenský, řešíme i dnes.
Jak název Komenského díla napovídá, jádrem je neutuchající zápas o lidství a lidskost. Lidství je nám dáno, lidskost je úkol. Rodíme se jako lidé s jedinečným potenciálem, otázka zní, jak s ním nakládáme. „Lidskost není docela v pořádku, ale není docela ztracena," tak zní výchozí antropologický předpoklad Porady. Naše lidství je rozporuplné, podle Komenského. Máme vynikající potenciál, mnoho víme, mnoho umíme, mnoho můžeme, ale právě tato naše kapacita je naší největší hrozbou. Všechno, čím disponujeme, dokážeme zneužít. At́ jde o náš rozum, vůli, emoce, vztahy, tvořivost nebo humor, naprosto vše umíme užít dobře i zle, usus i abusus, ř́kal Komenský. Jsme jediné 
bytosti, které mají potenciál sebezničení. Výzva $\mathrm{k}$ poradě, jak uskutečňovat náš potenciál lidsky, je proto svrchovaně aktuální a žádoucí.

\section{O čem je Komenského Porada}

Je třeba rozumět, že v Komenského době se Evropa ocitá v důsledku válečného, náboženského a politického běsnění na pokraji zkázy (pokolikáté už?). Lidé hledají své vlastní blaho bez ohledu na blaho celku. Ovšem blaho žádného jedince není možné bez blaha celku. Proto Komenský k poradě o nápravě zve všechny lidi, zvláště pak „světla Evropy“, tj. lidi, kteří mají moc řídit věci lidské - vladaře a učence. Důraz na celistvost či všeobecnost Porady je patrná z předpony "pan“, kterou předřazuje veškerému nápravnému úsilí. Své dílo člení do sedmi částí:

1. Panegersia (V̌̌eobecné probouzení): Má-li nastat jakákoli náprava, musí se lidstvo probudit a prozrrít, že má reálný globální problém. Jsme zaneprázdněni svými záležitostmi, ale uniká nám celek. Avšak člověku se nevede dobře, pokud se nevede dobře celé společnosti. Proto Komenský burcuje, probouzí vnímavost vůči našim společným problémům. Nejprve vyslovuje, co jsou to ,věci lidské" - jde o to, jak se člověk vztahuje: a) $\mathrm{k}$ věcem kolem sebe, b) $\mathrm{k}$ sobě, resp. $\mathrm{k}$ druhým lidem, a c) $\mathrm{k}$ Bohu. Stručně: vzdělání, politika, náboženství. Dále Komenský v této části dokládá porušení těchto věcí v dějinách lidstva a načrtává možnosti jejich nápravy.
2. Panaugia (V̌̌eobecné osvícení): V této části Komenský rozehrává symboliku světla jakožto nástroje přemáhání lidské temnoty a zmatků. Lidská mysl potřebuje „světlo“, aby bylo zřejmé, co je třeba znát, chtít a konat $\mathrm{k}$ nápravě, ba i záchraně věcí lidských. Člověku jsou dány tři zdroje světla, čili „svítilny“: svět, člověk, bible, tj. makrokosmos, mikrokosmos, Písmo. Nebo také: a) prrirozený svět nesoucí stopy stvořitelské moudrosti, b) lidský duch jakožto nositel Božího obrazu, c) Písmo vyjadřující Boží vůli pro člověka. Komenský toto někdy nazývá též „tři knihy“, ze kterých člověk může číst vše, co potřebuje znát $\mathrm{k}$ dobrému životu.

3. Pansofia (Všeobecná moudrost): Jedná se o svéráznou encyklopedii veškerého lidského poznání a také úsilí. Má osm částí, které Komenský nazývá stupně nebo též světy či vrstvy. Sedm světů je pojato jako záznam dějinného dramatu našeho kosmu - od stvoření dokonalého světa přes jeho pokažení, pád člověka do zlého, dále $\mathrm{k}$ světu materiálnímu, přirozenému a odtud opět vzestupně $\mathrm{k}$ nové duchovní dokonalosti. Vrcholem i základem všech světů je „svět možný“ - ideál, ke kterému je třeba směřovat. Pochopení světa i jeho dějin jako harmonického celku, který má spásný smysl, směřování i cíl, je základem oné vše-moudrosti. Nejde tu o vědění všeho, ale všeho potřebného $\mathrm{k}$ dobrému životu, resp. k nápravě. (Pansofie je nejrozsáhlejší částí Porady, je delší než všechny ostatní části dohromady.) 
4. Pampaedia (V̌̌e-vzdělávání nebo též univerzální vzdělávání): $\mathrm{V}$ celku Porady hraje klíčovou roli, protože jeho smyslem je předávání výše zmíněné vše-moudrosti. Jedná se o originální celistvou filosofii výchovy nebo též filosofii celoživotního utváření člově$\mathrm{ka}$, jejímž cílem je přivést všechny lidi k osvojení pansofického poznání, a to přirozeně, tj. bez násilí či donucování, protože násilí je v rozporu s podstatou Stvořitele i stvoření. Komenský vyjadřuje svou edukační teorii zásadou omnes, omnia, omnino (všechny, všemu, všestranně), která odpovídá na tř̌i fundamentální pedagogické otázky: koho vzdělávat, čemu a jak? Vzdělávat všechny lidi, všemu, čeho je třeba $\mathrm{k}$ dobrému životu, všemi možnými a vhodnými prostředky.

5. Panglottia (Vše-mluva): Jelikož cílem poradního díla je celospolečenská náprava, navrhuje Komenský velmi pragmaticky, aby se národy sjednotily na jedné řeči, která by byla srozumitelná všem. Nemíní nahradit rodné jazyky jazykem univerzálním, ale doporučuje zušlechtovat rodné jazyky tak, aby byly schopné komunikovat veškerou moudrost, která je člověku $\mathrm{k}$ dispozici, a k tomu navíc doporučuje všem osvojit si jazyk univerzální, kterým lze komunikovat s ostatními.

6. Panorthosia (Vše-náprava): $\mathrm{V}$ této části Komenský předkládá konkrétní postup nápravy. Začíná u sebe, u jednotlivce, dále se musí náprava šírit skrze rodiny, školy, církve, státy až po celek společnosti. Nadčasovým vhledem Komenského je instituční zakotvení nápravného úsilí: má-li nastat náprava, je třeba součinnosti klíčových správních, ale i vědeckých (osvětových) institucí - místních, národních i mezinárodních. Cílem je nastolení porozumění a míru mezi jednotlivci i národy.

7. Pannuthesia: (V̌̌eobecné povzbuzení): Jestliže první kniha Porady hleděla do minulosti, $\mathrm{k}$ př́čcinám problémů lidstva, tato poslední kniha je pohledem do budoucnosti, do budoucích možností lidstva. Kniha je nedokončena, spíše v poznámkách. Ale i tak je z ní cítit intenzita a naléhavost, $s$ jakou Komenský apeluje na všechny lidi bez výjimky, aby se účastnili nápravného úsilí.

\section{Co s tím po 350 letech?}

Není to utopie? Jako ta Moorova, Campanelova nebo Baconova? Nedopouští se Komenský starého omylu, že když budou mít lidé správné poznání, budou také správně jednat? Některé jednotlivé výroky Jana Amose tak mohou znít, ale dílo ve svém celku vyznívá jinak. Komenský sice vede k „pravdivému poznávání", protože mnohé z lidských zmatků plynou z omylů či prosté neznalosti (on sám se v mnohém mýlil). Zároveň si je však vědom, že porušenost lidství se netýká pouze rozumu. Je třeba vědět, chtít a moci (scire, velle, posse), opakuje častokrát. Náprava se tedy musí týkat i vůle, charakteru a vůbec celého člověka. 


\section{VIZE PROJEKTU}

„Takový bude př́ští věk, jak budou vychováni jeho př́ístí občané, “ rúká Komenský v Poradě. Dobrou společnost nelze vytvořit bez dobrých jedinců, resp. občanů. Projekt vědomě usiloval (a bude i nadále usilovat) o rozvoj znalostí, dovedností a kompetencí, které napomáhají souladu mezi "dobrem“ jedince a "dobrem" celku demokratické společnosti.

Lidskou společností hýbe sedm klíčových hybatelů, resp. „věcí lidských“, jak o nich hovoří Komenský ve zmíněné Poradě. Tyto hybné momenty tvoří obsahovou osnovu projektu:

- politika (vláda),

- média (jazyk),

- byznys (podnikavost),

- spiritualita (náboženství),

- vzdělání (výchova),

- kultura (umění),

- rodina (vztahy).

Konkrétní vzdělávací program projektu je založen na principu pozitivní motivace skrze tzv. morální imaginaci. Respektive nejde o to primárně poukazovat no to, co je ve společnosti špatně, ale naopak probouzet představivost v dobrém: Jak by vypadala politika, která by byla skutečně dobrá, tj. funkční z hlediska dlouhodobé udržitelnosti demokratické kultury? Podobně: Jak vypadají dobrá média? Dobré podnikání? Dobré náboženství? Dobré vzdělání? Dobré umění? Dobrá rodina? Pod př́vlastkem „dobrýc máme na mysli funkční, prospívající nebo životný, a to pro jedince i celek demokratické společnosti.

\section{Co SE PODAŘILO}

Tříleté prrípravy projektu vyvrcholily na podzim roku 2020 (přesné datum výročí je 15 . listopadu). $\mathrm{V}$ rámci projektu vznikl web komensky2020.cz. Pro mladou generaci byla vytvořena interaktivní kniha, která zábavnou formou přibližuje „věci lidské“ podle Komenského. U každé oblasti jsou ke zhlédnutí krátká videa, kde se mladí lidé mají možnost seznámit nejen s myšlenkami Komenského, ale také se známými osobnostmi jako jsou Ondřej Šteffl, Daniel Kroupa, Janek Rubeš, Marek Eben a další. Interaktivní kniha je protkána komiksem přibližujícím život Komenského a jeho citáty, které namluvil herec Pavel Rímský. Interaktivní kniha je k dispozici také ke stažení v mobilní aplikaci. Dále bylo vytvořeno 48 vzdělávacích metodik s názvem Komenský pro život pro 1. i 2. stupeň Z Š a první dva ročníky SŠ/SOŠ/SOU.

Bylo vyškoleno přes 50 lektorů po celé ČR, kteří prostřednictvím vzdělávacích programů pro základní a střední školy seznamují žáky a studenty praktickou formou s životem a hlavními myšlenkami Komenského. $\mathrm{Na}$ školách lektoři realizovali 318 programů a oslovili tak 6000 žáků a studentů.

Jedním z klíčových motivů projektu byla aktivizace mládeže, výzva $\mathrm{k}$ činu. Školy a tř́́dní kolektivy byly vyzvány 
k tzv. PROPPRO, Projektům proměny. Jedna věc je pojmenovat problémy „věcí lidských", jiná je s nimi něco udělat. V projektu Komenský 2020 nešlo o to pouze popularizovat ideje nebo pouze mluvit o problémech, ale něco udělat. Ovlivnění některých problémů a záležitostí je zcela mimo možnosti většiny z nás, občanů, natož žáků a studentů. Ovšem některé věci jsou v našich možnostech, a proto s nimi lze něco udělat. Jedním z klíčových cílů proto bylo identifikovat právě ty „věci lidské“, jejichž náprava je proveditelná. Projekt nabízí platformu ke konkrétní akci v obci, regionu nebo na celonárodní úrovni - podle možností realizátorů. Každý jedinec či kolektiv (školní tř́ída, klub, kroužek apod.) je zván $\mathrm{k}$ „nápravě věcí lidských“, které jsou v jeho moci. Do Projektů proměny se registrovalo 30 tř́dních kolektivů, které se rozhodly - inspirovány Komenským - učinit konkrétní dobrou věc ve svém okolí. Česká televize zdokumentovala vítězný Projekt proměny skupiny žáků ze Ž̌ Dobřany, kteři proměnili neútulnou autobusovou zastávku v př́ijemný pokoj k odpočinku.

Školy, knihovny, veřejné instituce i angažovaní jednotlivci uspořádali veřejné čtení Komenského myšlenek včetně výstavy Komenského Timeline, a přispěli tak $\mathrm{k}$ propojení, aktivizaci a vzájemné inspiraci místní komuni- ty. Koronavirová pandemie na mnoha místech veřejné čtení omezila. Výstava zachycující významné události z Komenského života se konala na 285 místech v ČR. Většinou se jednalo o školy a knihovny.

$\mathrm{V}$ rámci projektu byla též realizována publikace s názvem To nejlepši z Komenského Obecné porady o nápravě věcí lidských shrnující klíčové citáty a statě z Komenského rozsáhlého díla.

$\mathrm{Na}$ YouTube kanále Komenský 2020 byla spuštěna osmidílná video-série youtubera a lektora Petra Kadlece Svèt, který má budoucnost a stejnojmenná populárně naučná série krátkých interpretací Porady.

\section{PoKRačování: KoMENSKÝ - PŘÍBĚHY LIDSKOSTI}

Projekt poznamenala koronavirová krize. Mnoho výstav, přednášek, konferencí a především Projektů proměny nemohlo být uskutečněno. Realizátoři se proto rozhodli v projektu pokračovat, a to až do roku 2022, kdy budeme slavit tentokrát 430. výročí Komenského narození. Projekt bude pokračovat s novým názvem: Komenský - př́běhy lidskosti. Nový název reflektuje zkušenost účastníků Projektů proměn, kteří realizaci svých projektů - podle vlastních slov - vyprávěli jako „př́iběhy lidskosti“.

doc. PhDr. Jan Hábl, Ph.D.

Univerzita Hradec Králové, Pedagogická fakulta, katedra pedagogiky a psychologie;

e-mail:jan.habl@uhk.cz 


\section{HÁBL, J. Project Comenius 2020}

Does humanity have a future? Are we heading irreversibly to perdition or should we expect a better tomorrow? How are we doing? The year 2020 provided an opportunity to reflect on the prospects of humanity, as it was a significant anniversary year. When Jan Amos Komensky died 350 years ago, he left behind his largest unfinished work, called The General Consultation on Restoration of Human Affairs (De rerum humanarum emendatione consultatio catholica). The work is beautiful, deep, and extensive. The original manuscript included some 2000 pages of text. The translation from Latin into Czech was divided into three volumes, each over five hundred pages. It is a magnificent project indeed, a unique work, a magnum opus, a literary treasure, and one of the sources of Europe's spiritual heritage. We still draw inspiration from it today. After all, the deepest human questions that Comenius dealt with are still being addressed today. What are human affairs, what is wrong with them, and also the most important question - can they be reformed, restored, or improved? The Comenius 2020 project sought to popularise Comenius' Consultation as well as his broader humanistic legacy.

Keywords: Comenius, restoration of human affairs, education, humanity 